\title{
Crop Models and Decision Support Systems for Yield Forecasting and Management of the Sugar Beet Crop
}

\author{
Hilde, J. Vandendriessche ${ }^{1 *}$ and M. K. van Ittersum ${ }^{2}$ \\ 1 Soil Service of Belgium, W. de Croylaan 48, 3001 Leuven, Belgium. \\ 2 Department of Theoretical Production Ecology, Wageningen Agricultural University, \\ P.O. Box 430, 6700 AK Wageningen, The Netherlands.
}

Accepted 22 June 1995.

* To whom correspondence should be addressed.

\begin{abstract}
Models for the sugar beet crop have been developed for various purposes : (i) sugar yield forecasting with regard to campaign planning and marketing strategies; (ii) integration of scientific knowledge and hypothesis testing; (iii) decision support, in particular tactical and operational decisions at the farm level. It is difficult to satisfy these three objectives with one model; each aim requires its own model. Available sugar beet models can be divided into descriptive models and explanatory models integrating various processes. The first are mainly used for prediction, the latter for research. For decision support and the management of the sugar beet crop at the farm level a combination of descriptive or explanatory crop models, databases and expert systems may be used.

This paper gives a comprehensive review of models used to forecast yield and of mechanistic models and decision support systems. Analysis of the literature revealed that so far no models are available to simulate sugar beet quality.
\end{abstract}

Key-words : crop models, decision support systems, sugar beet (Beta vulgaris L.).

\section{INTRODUCTION}

Crop models may have various objectives. Seligman (1990) lists these objectives as: "hypothesis generation and hypothesis testing, sensitivity analysis, finding 'gaps in knowledge about the system' as a guide to further research, interdisciplinary integration, improved crop management strategies, regional planning, identification and evaluation of plant characteristics that can help to define plant breeding aims, better understanding of complex crop responses'.

The factors that contributed to the development of sugar beet models are: (1) sugar yield forecasting with regard to production planning and economy; (2) integration of scientific knowledge and hypothesis testing in research; (3) decision support in particular for tactical and operational decisions on farm level.

Sugar beet models range from very detailed process descriptions, like the SUBGRO model (Fick, 1971), to relatively simple process formulations (Feyen and Van Aelst, 1983). It is noted that the complexity of a crop model and the level of detail with which system com- ponents are described, are related to and depend on the purpose for which the model is developed.

For yield forecasting the most simple approach is to regress environmental variable(s) against yield. In general empirical models are easy to use and successful when applied within the range of sites and weather circumstances for which they have been developed and tested (France and Thornley, 1984). For research purposes, it is often required to include in the model a detailed description of the underlying processes. In these models' well-understood processes are formulated in a mechanistic way, and for those system components of which the mechanism is not yet unravelled, empirical relations are used to relate input to output (France and Thornley, 1984).

According to Penning de Vries (1983) and Krupa et al. (1992) the statistical regression models and the mechanistic process models with respectively a low and a high degree of complexity are both judged as to have a medium predictive value. The precision of responses is, according to the same authors, low to medium for mechanistic models and high for statisti- 
cal models if there is no extrapolation outside the range of the original database.

This paper reviews the various types of sugar beet models, including a brief description of the models discussed. The review illustrates the different scopes, natures and purposes for which models are designed.

\section{EMPIRICAL MODELS FOR YIELD FORECASTING}

Accurate production forecasts are indispensable for the sugar industry for different reasons, first for processing the sugar beet crop and secondly for the marketing of sugar and its by-products. The processing of sugar beets must be well organized : beet is perishable, reliable plans of factory operations concerning delivery schedules and storage capacity are necessary, opening and closing dates of the factories and the need for fuel and other raw materials must be planned. Costs increase when the campaign ends late and thus yield prediction is a useful aid to marketing operations where prices of sugar fluctuate in response to demand and supply, and where the use of molasses in animal feeding stuffs is price-sensitive. Also, the European Union (EU) is very interested in timely, quantitative forecasts of the expected mean crop yields (including sugar beet) for the definition and implementation of the common agricultural policy (Vossen, 1992).

Yield forecasting is, with the exception of farmers' interests, mainly needed on a regional scale. Neither industry nor policy is interested in yield forecasts at the field or farm level. The EU needs forecasts at the scale of a country, large regions or the whole EU. To be useful for the sugar industry, the spatial scale of yield forecasting should be related to the region from where the refinery is contracting sugar beets. Regional yield forecasts on behalf of the sugar industry are made in Belgium, England, Germany, Sweden, the Netherlands, etc. In countries where substantial variations in climatic conditions occur from region to region, research in yield forecasting is elaborated for each sub-region.

In the past, various methods for estimating yield have been developed. The different methods can be classified as empirical or mechanistic. Whatever the method, it has to be accurate, reliable and costeffective.

Traditionally beet and sugar yield forecasts are based on pre-harvest sugar beet samples (Scott and Jaggard, 1993). The procedure and the extent of beet sampling depend on guidelines developed by the sugar beet companies (Church and Gnanasakthy, 1983 ; van der Beek, 1993 ; etc.). The procedures are all different, but have the same objective and show important similarities. At regular time intervals throughout the growing season samples of sugar beet plants are taken from representative fields at one to two week intervals. The number of fields sampled is proportional to the sugar beet area. The size of the sample varies from a few beets to several metres of row. The relation between sampled plant material and observed yields, derived in preceding years, is used to forecast yields. Because of the regional relevancy of the relations, they are seldom published in international journals.

This above-described statistical procedure to forecast yields is simple and straightforward, and therefore applied in many countries. Notwithstanding, the approach shows a number of important disadvantages. The periodic harvesting of plant material is labourintensive. Furthermore, the samples may be a poor representation of the field, due to large variations that can exist in a field. Before the method can be used in practice or if any major alteration to the method is carried out, data sets over several years are necessary to provide reliable forecasts. No insight in the underlying causes of year-to-year variation is given. Because of these disadvantages a number of empirical models have been developed.

Many attempts have been made to relate root and sugar yields directly to various aspects of climate and to environmental parameters. The most important factors used are rainfall, temperature and solar radiation, and sometimes fertilizer or nutrient status (Spitters et al., 1990; Jaggard, 1992; Mambelli et al., 1992 ; Modig, 1992; Yücel, 1992). A few semi-empirical models are improved by accounting for the effect of suboptimal water transport in the soil-plantatmosphere system using a soil moisture balance or by calculating the relative transpiration rate, using simplified concepts such as logistic curves with an independent variable (i.e. sugar yield) as a function of the water deficit (Mambelli et al., 1992 ; Feyen and Van Aelst, 1983). To update the model for yield prediction at the time of harvest, intermediate harvest or remote sensing information about the crop canopy and about the acreage occupied by sugar beet is often used (Maas, 1988; Jaggard and Clark, 1990; Bouman, 1991 ; Jaggard, 1992 ; Vossen, 1992).

Table 1 summarizes some of the empirical sugar beet models used for predicting crop growth and yield. Models in Table 1 with an asterisk are mainly used by the sugar industry to predict the total yield of large areas. The other models described in Table 1 are hardly used in practice, although efforts are made to test the accuracy and reliability of these models (see column labelled 'Results'). The inputs (Table 1) for empirical models consist mostly of a combination of weather data, planting or emergence date and sample data collected on commercial fields. Weather data requirements vary from averages for a day, a week, two weeks, a month or a larger fraction of the growing season. The mathematical methods used are linear regression, non-linear regression, linear integration or a combination of different regressions.

Comparisons of model predictions with observed data indicate that these empirical models can account 
Table 1. Main characteristics of some published empirical sugar beet models with regard to crop and yield forecasting.

\begin{tabular}{|c|c|c|c|c|}
\hline Objectives $\left({ }^{1}\right)$ & $\begin{array}{l}\text { Factors }\left({ }^{2}\right) \text { involved } \\
\text { in the model }\end{array}$ & Method & Results & Reference \\
\hline $\begin{array}{l}\text { Very early (June 1) and } \\
\text { early (June) forecasts of } \\
\text { root (B) and sugar (S) } \\
\text { yield in Sweden }\end{array}$ & $\begin{array}{l}\text { Time of the year }(y) \text {, average } \\
\text { sowing date }(s) \text {, average tempe- } \\
\text { rature of May ( } 15) \text {, (average } \\
\text { temperature of June ( }(16) \text {, } \\
\text { rainfall of June }(r 6))\end{array}$ & $\begin{array}{l}\text { Linear regressions of } \\
\text { the dependent varia- } \\
\text { bles } \mathrm{B} \text { and } \mathrm{S} \text { on } \\
(y, s, t 5) \\
(y, s, t 5, t 6) \\
(y, s, t 5,16,16)\end{array}$ & $\begin{array}{l}\text { Relative efficiency (r.e.) of } \\
60 \% \text { for sugar yield and } 70 \% \\
\text { for root yield at forecasts on } \\
\text { June } 1 \text { st. Later the r.e. increases } \\
\text { to } 66 \% \text { and } 80 \%\end{array}$ & Modig, 1992 \\
\hline $\begin{array}{l}\text { Forecast from August } 1 \\
\text { until the beginning of } \\
\text { the campaign for root } \\
\text { and sugar yield in } \\
\text { Sweden }(*)\end{array}$ & $\begin{array}{l}\text { Weather data; sample investiga- } \\
\text { tions of the commercial beet } \\
\text { growing (plant number, beet } \\
\text { weights, beet quality) }\end{array}$ & $\begin{array}{l}\text { Linear regression } \\
\text { models of the depen- } \\
\text { dent variables } \mathrm{B} \text { and } \\
\mathrm{S} \text { on a mix of } \\
\text { weather data and } \\
\text { sample investigations }\end{array}$ & $\begin{array}{l}\text { Current system for official } \\
\text { forecasts of root yield and } \\
\text { sugar yield in Sweden }\end{array}$ & Modig, 1992 \\
\hline $\begin{array}{l}\text { Forecast of sugar yield } \\
\text { in England }(*)\end{array}$ & $\begin{array}{l}\text { Solar irradiance, light intercep- } \\
\text { tion (sowing data, spectrophoto- } \\
\text { metry), temperature, conversion } \\
\text { coefficient of solar energy to } \\
\text { stored sugar }\end{array}$ & $\begin{array}{l}\text { Linear integrations of } \\
\text { the fraction of light } \\
\text { intercepted by the } \\
\text { beet crop during } \\
\text { growing season }\end{array}$ & $\begin{array}{l}\text { Predictions-actual yield compa- } \\
\text { risons : } 1987-1990 \text {; } \\
\text { Predictions first made in June } \\
\text { and revised when required by } \\
\text { the sugar factory managers }\end{array}$ & Jaggard, 1992 \\
\hline $\begin{array}{l}\text { Prediction of root growth } \\
\text { and sugar yield of } \\
\text { spring-sown sugar beet } \\
\text { under Po-valley condi- } \\
\text { tions }\end{array}$ & $\begin{array}{l}\text { Average daily temperature, and } \\
\text { daily rainfall and irrigation from } \\
\text { emergence to final harvest }\end{array}$ & $\begin{array}{l}\text { Logistic growth curves } \\
\text { with growing degree } \\
\text { days and water deficit } \\
\text { calculations as indepen- } \\
\text { dent variables. }\end{array}$ & $\begin{array}{l}\text { Comparison between measured } \\
\text { and simulated data is done for } \\
\text { both rainfed and irrigated sugar } \\
\text { beet experiments }\end{array}$ & $\begin{array}{l}\text { Mambelli et al., } \\
1992 \text {. }\end{array}$ \\
\hline $\begin{array}{l}\text { Relationship between } \\
\text { environmental factors, } \\
\text { yield (Y1) and sugar } \\
\text { (Y2) quality in different } \\
\text { climatic zones in Turkey }\end{array}$ & $\begin{array}{l}\text { Climatic data, fertilizer (N, P, K) } \\
\text { applications }\end{array}$ & $\begin{array}{l}\text { Regression equations } \\
\text { of the dependent } \\
\text { variables } \mathrm{Y} 1 \text { and } \mathrm{Y} 2 \\
\text { on different combina- } \\
\text { tions of the indepen- } \\
\text { dent factors }\end{array}$ & $\begin{array}{l}\text { Indication of the importance of } \\
\text { irrigation from sowing until the } \\
\text { end of June and during possi- } \\
\text { ble dry periods in July and } \\
\text { August }\end{array}$ & Yücel, 1992 \\
\hline $\begin{array}{l}\text { Prediction of seasonal } \\
\text { growth, sugar beet yield } \\
\text { and of 'growing point } \\
\text { data' with LUTIL: Light } \\
\text { UTILisation simulator }\end{array}$ & $\begin{array}{l}\text { Sowing data, incoming solar } \\
\text { radiation, temperature, region } \\
\text { specific multiplication factor }\end{array}$ & Regression equations & $\begin{array}{l}70 \% \text { and } 65 \% \text { of the varia- } \\
\text { tion between years within } \\
\text { regions is explained by the } \\
\text { model for sugar yield and beet } \\
\text { fresh yield, respectively }\end{array}$ & $\begin{array}{l}\text { Spitters et al., } \\
1989,1990\end{array}$ \\
\hline $\begin{array}{l}\text { Interpretation of variation } \\
\text { between years in the } \\
\text { early growth of sugar } \\
\text { beet }\end{array}$ & Temperature, radiation & $\begin{array}{l}\text { Hyperbolic growth } \\
\text { rate model; leaf area } \\
\text { index as a linear } \\
\text { function of temperatu- } \\
\text { resum; exponential } \\
\text { relation between inter- } \\
\text { cepted radiation and } \\
\text { leaf area }\end{array}$ & $\begin{array}{l}\text { The model accounts for diffe- } \\
\text { rences in weather between } \\
\text { years with significant effect on } \\
\text { dry matter increase before } \\
\text { complete canopy cover }\end{array}$ & Day, 1986 \\
\hline $\begin{array}{l}\text { PIEteR; Production model } \\
\text { to predict 'growing point } \\
\text { data' (GPD), root and } \\
\text { sugar yield }\end{array}$ & Weather data; soil data & $\begin{array}{l}\text { Non-linear regression } \\
\text { equations }\end{array}$ & $\begin{array}{l}\text { PIEteR is tested for more than } \\
3000 \text { sugarbeet fields in 1991, } \\
\text { with a good prediction of GPD } \\
\text { and national sugar yield for the } \\
\text { IRS data (The Netherlands) }\end{array}$ & $\begin{array}{l}\text { Biemond et al., } \\
1989 \\
\text { Smit et al., } \\
1993\end{array}$ \\
\hline
\end{tabular}

(*) Applied in large sugar beet factory areas.

(') Dependent variables in the case of regression models.

$\left({ }^{2}\right)$ Independent variables in the case of regression models. 
for yield and sugar variations for the sugar beet crop with a high degree of accuracy. In column 4 of Table 1 some results obtained with these empirical models are given (i.e. the percentage of the variation between years within regions which is explained by the model LUTIL (Spitters et al., 1989, 1990)). However, there are limitations to the generality of the models, necessitating different models for different regions, and no explanation is given for the effect of environmental factors on root and sugar yield. In fact, these empirical and descriptive models represent the statistical analysis of crop-weather relations. To build in underlying mechanisms and their interactions, mechanistic models have been developed.

\section{MECHANISTIC MODELS}

Mechanistic models of crop growth assume that the system has a known structure, and that properties and processes of the components of the system can be described mathematically. Table 2 gives a listing of the processes commonly considered in mechanistic models. The classification of the processes in Table 2 is based on France and Thornley (1984), and expanded with processes specific for sugar beet growth, yield and quality. Most sugar beet models consider different combinations of processes and treat them in various ways relevant to the system being studied.

Mechanistic sugar beet models are typically explanatory models and integrate the processes involved at different levels. The levels may be the sugar beet crop, the sugar beet plant, sugar beet organs (roots, crowns, leaves and fibrous roots), sugar beet tissues (of leaves, petioles, crowns and roots). The response at a given level can be related to responses at lower levels, i.e. 'scientific reductionism' (Thornley and Johnson, 1990).

An overview of most of the published, mechanistic sugar beet growth models is given in Table 3 . The models simulate sugar beet growth at different produc- tion levels : (1) potential production (SUBGRO, SUBGOL, SUBEMO, SUCROS1, the model of Patefield and Austin, 1971); (2) water limited production (SUCROS2, SIUCRA); and (3) nutrient limited production (SIMBEET, SOWAN, the model of Frere et al., 1970). The objectives of the models are preponderantly for integrating knowledge and testing hypotheses. However most of the models have predictive power since there are easily measurable output variables such as root yield, shoot yield and sugar yield.

Frere et al. (1970) described a soil-water-nitrogenplant model to estimate the behaviour of water and nitrogen in the root zone from crop emergence to harvest. With increasing competition for water and concern for the nitrate pollution of our environment, agriculture must optimize these growth factors. Since irrigation water may leach nitrate out of the root zone, the system cannot be optimized by considering these variables separately. Therefore a set of mathematical relations was developed for the major variables of soil water, nitrate, ammonium, available organic nitrogen, and plant growth and nitrogen uptake. Daily weather data were used to calculate evapotranspiration and modify the rates of soil processes and plant growth. The authors made an effort to keep the model general so that it could be used for other crops, climates, and soils. However some specific numerical values as crop coefficients, used to develop the model, were derived from irrigated sugar beet experiments on a Portneuf silt loam in Idaho.

SUBGRO (Fick, 1971) is a mechanistic simulation model. A key feature of this model is the partitioning of photosynthates from a pool of 'reserves' to respiration, growth and storage. The partitioning involves: (1) the basic growth rate of the sink as a function of temperature and the amount of tissue capable of growth; (2) the effect of reserve supply in limiting potential growth; and, (3) the effect of internal water status of the plant in limiting growth. Versions I and II of SUBGRO differ in their modelling of the sugar accumulation mechanism. Some limitations of the SUBGRO model are that respiration is only handled as a percentage of the carbohydrate produced by pho-

Table 2. Processes that are important in mechanistic sugar beet growth models.

\begin{tabular}{|c|c|c|}
\hline 1 & PHOT & Light interception and photosynthesis : canopy architecture; radiation characteristics; leaf characteristics \\
\hline 2 & GR and $\mathrm{R}$ & Growth of structural dry matter and the recycling of structural components; respiration \\
\hline 3 & TRANSP & Transpiration : water balance of plant and soil: water status of plant \\
\hline 4 & PART & $\begin{array}{l}\text { Partitioning: substrate pools of carbon compounds and nutrients replenished by (PHOT) and } 6 \text { (DEVEL); } \\
\text { transport between pools; utilization of pool substances for growth; priorities }\end{array}$ \\
\hline 5 & LAexpl & Leaf area expansion \\
\hline 6 & DEVEL & Development and morphogenesis : initiation, growth and development of new organs (stems, leaves, roots etc.) \\
\hline 7 & SENES & Senescence \\
\hline 9 & NUTR & Root activity and nutrient uptake : root system architecture; soil nutrient status; root status and characteristics \\
\hline 10 & BEETQ & Beet quality in terms of $\alpha$-amino-nitrogen, potassium and sodium content \\
\hline
\end{tabular}


Table 3. Processes involved and main characteristics of some published mechanistic sugar beet growth models.

\begin{tabular}{|c|c|c|c|c|c|c|c|c|c|c|}
\hline & Model name & $\begin{array}{c}\text { Unnamed } \\
1\end{array}$ & SUBGRO & SUBGOL & $\begin{array}{c}\text { Unnamed } \\
2\end{array}$ & SUCROS & SIMBEET & SOWAN & SUBEMO & SIUCRA \\
\hline \multirow{5}{*}{$\begin{array}{l}\text { Main } \\
\text { objectives }\end{array}$} & scientific & & $\mathrm{x}$ & $\mathrm{x}$ & $\mathrm{x}$ & $\mathrm{x}$ & $\mathrm{x}$ & $\mathrm{x}$ & $\mathrm{x}$ & $\mathrm{x}$ \\
\hline & understanding & & & & & & & & & \\
\hline & hypothesis testing & & $\mathrm{x}$ & $\mathrm{x}$ & $\mathrm{x}$ & & & & & \\
\hline & forecasting & $(x)$ & (x) & (x) & $x$ & (x) & $\mathrm{x}$ & (x) & $(x)$ & $\mathrm{x}$ \\
\hline & management & (x) & & & & & $\mathrm{x}$ & & & . \\
\hline \multirow[t]{3}{*}{ Input data } & climatic & $\mathrm{x}$ & $\mathrm{x}$ & $\mathrm{x}$ & $\mathrm{x}$ & $\mathrm{x}$ & $x$ & $\mathrm{x}$ & $\mathrm{x}$ & $\mathrm{x}$ \\
\hline & crop specific & $x$ & $\mathrm{x}$ & $x$ & $\mathrm{x}$ & $x$ & $\mathrm{x}$ & $\mathrm{x}$ & $\mathrm{x}$ & $\mathrm{x}$ \\
\hline & environmental & $\mathrm{x}$ & & & & (x) & $\mathrm{x}$ & $\mathrm{x}$ & & \\
\hline \multirow[t]{2}{*}{ Time step } & hour & & $\mathrm{x}$ & $x$ & & & $\mathrm{x}$ & & $\mathrm{x}$ & \\
\hline & day & $\mathrm{x}$ & & & $\mathrm{x}$ & $\mathrm{x}$ & & $\mathrm{x}$ & & $\mathrm{x}$ \\
\hline \multirow{8}{*}{$\begin{array}{l}\text { Processes } \\
\text { treated in } \\
\text { submodels } \\
\text { for crop } \\
\text { growth (see } \\
\text { Table 2) }\end{array}$} & PHOT & $\mathrm{x}$ & $\mathbf{x}$ & $x$ & $x$ & $x$ & $\mathrm{x}$ & $\mathrm{x}$ & $\mathrm{x}$ & $x$ \\
\hline & PART & & $\mathrm{x}$ & $\mathrm{x}$ & $\mathrm{x}$ & $\mathbf{x}$ & $\mathrm{x}$ & $\mathbf{x}$ & . $\quad x$ & : $\quad x \ldots$ \\
\hline & $L A \exp$ & & $x$ & $\mathrm{x}$ & & $\mathrm{x}$ & $\mathrm{x}$ & & $\therefore \quad \mathrm{x}$ & 1,1 \\
\hline & DEVEL & & $\mathrm{x}$ & $\mathbf{x}$ & & $x$ & & & $x$ & $x$ \\
\hline & SENES & & & $\mathrm{x}$ & & & $\mathrm{x}$ & & & $\because 1$ \\
\hline & SUGARC & & $\mathrm{x}$ & $\mathrm{x}$ & & & $\mathrm{x}$ & & $\mathrm{x}:$ & $: \mathbf{x}$ \\
\hline & NUTR & $x$ & & & & & $\mathrm{x}$ & $\mathrm{x}$ & $\cdots:$ & $1:$ \\
\hline & BEETQ & & & & & & & & & $\ldots$ \\
\hline \multirow{2}{*}{$\begin{array}{l}\text { Interactions } \\
\text { with soil }\end{array}$} & soil moisture & $\mathrm{x}$ & & & & $(x)$ & & $\mathrm{x}$ & & \\
\hline & mineral nitrogen & $x \cdot \cdot$ & & & & $(x)$ & & $\mathrm{x}$ & & \\
\hline \multirow{4}{*}{$\begin{array}{l}\text { Computer } \\
\text { language }\end{array}$} & FORTRAN & $\mathrm{x}$ & & & & $(x)$ & $\mathrm{x}$ & $\mathrm{x}$ & $\mathrm{x}$ & $\mathrm{x}$ \\
\hline & CSMP & & $\mathbf{x}$ & . & & $x$ & 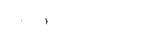 & & & \\
\hline & Algol & & & $\mathrm{x}$ & & & & & & \\
\hline & EMA & & & & $\mathrm{x}$ & & & & & \\
\hline
\end{tabular}

References: Unnamed 1, Frere et al., 1970; SUBGRO, Fick, 1971; Fick et al., 1973, 1975; SUBGOL, Hunt, 1974; Hunt and Loomis, 1979; Unnamed 2, Patefield and Austin, 1971; SUCROS, van Keulen and van Laar, 1982; Spitters et al., 1989; van Laar et al., 1992; SIMBEET, Lee, 1983; SOWAN, Hendrickx, 1986; SUBEMO, Vandendriessche, 1989; SIUCRA, Burke, 1992

(x) Optional.

tosynthesis, the effect of nitrogen on sugar beet growth is not included, nor is the dry matter loss from leaf senescence.

The SUBGOL model developed by Hunt (1974), is a modification of SUBGRO. Hunt defines the respiratory system in a submodel and predicts respiration related to both growth and maintenance requirements. Further, SUBGOL contains an elementary senescence section in which leaf death-rate increases with age and mutual shading of leaves.

In 1965 Monteith and de Wit both developed their own models for the potential daily production of a given canopy. Their models describe daily potential photosynthesis of leaf canopies from knowledge of the incoming short-wave radiation, the day length, the relationship between light intensity and photosynthesis, the light-interception characteristics of the foliage, and the leaf-area index. Both models resulted in simplified dynamic sugar beet models. Monteith's (1965) model resulted in a simple explanatory model of Pate- field and Austin (1971) for the simulation of the growth of Beta vulgaris L., cv. Detroit Early Globe, a red table beet. De Wit's model was an early forerunner of SUCROS (van Laar et al., 1992).

The Patefield and Austin (1971) model assumes that the photosynthesis and respiration rates of the plant are functions of the prevailing temperature and light intensity, and that the past temperature and light experience have no effect on the current photosynthesis and respiration rates other than through effects on the size of the plant. For the allocation of net photosynthate, there is no theoretical basis in the model. Instead, the model uses the observed distribution pattern of dry matter and an empirical allometric relation between leaf weight and total weight, for the partitioning of photosynthates.

SUCROS (van Laar et al., 1992) stands for a Simple and Universal CROp growth Simulator. SUCROS 1 simulates potential growth of a crop, i.e. dry matter accumulation under ample supply of water 
and nutrients in a pest-, disease- and weed-free environment under prevailing weather conditions. The basis for calculating dry matter production is the rate of gross $\mathrm{CO}_{2}$ assimilation of the canopy. This rate is dependent on the radiant energy absorbed by the canopy, which is a function of incoming radiation and leaf area. From the absorbed radiation and the photosynthetic characteristics of single leaves, the daily rate of $\mathrm{CO}_{2}$ assimilation of the crop is calculated. Part of the carbohydrates produced are used to maintain the present biomass. The remaining carbohydrates are converted into structural dry matter. In this conversion, some of the weight is lost as growth respiration. The dry matter produced is partitioned amongst the various plant organs, using partitioning factors introduced as a function of the phenological development stage of the crop (Spitters et al., 1989). SUCROS2 describes production under water-limited conditions using a soil water balance. SUCROS is used by different modellers for various purposes. Kropff (1993) extended the SUCROS model to an eco-physiological simulation model, the INTERCOM-model, taking into consideration the impact of the competition between sugar beet and weed on yield. Van der Werf (1988) calculated the reducing effect of beet yellow viruses on final yield of sugar beet with SUCROS. The SBFLEVO-model (Bouman, 1992) combines SUCROS with knowledge on the interaction of optical radiation and microwaves with crop canopies. This makes it possible to improve model simulations by the use of some actual information on the growth and development of the field crops measured by remote sensing. The SUCROS-Cloud-EXTRAD model uses the same methodology (Bouman, 1991).

The model SIMBEET (Lee, 1983) was developed to understand the interactions between plant morphology and physiology, and the environment. Photosynthesis, respiration, translocation, growth, root sucrose storage, senescence and synthesis/mobilization of starch are expressed mathematically" to simulate dry matter accumulation patterns of sugar beets with a time-step of one hour. Each physiological process rate is calculated by multiplying a maximum possible rate by a series of factors which account for the effect of temperature, age of the plant, nitrogen, solar radiation, and nonstructural carbohydrate on the physiological rate. According to Lee (1983) the translocation rate equations are the poorest developed components in SIMBEET.

SOWAN (Hendrickx, 1986) is a summary model which connects dry matter production of sugar beet with a nitrogen- and soil water balance. The model component for the simulation of the beet crop is based on the SUCROS model. For the simulation of the soil water balance procedures are taken from the models SWATRE (Belmans et al., 1982), PAPRAN (Seligman and van Keulen, 1981), and CERES (Ritchie, 1984). The nitrogen submodel is a simple description of the different subprocesses of the mineral nitrogen balance such as mineralisation, denitrification, nitrification, fertilization and N-uptake. All these subprocesses are simulated for several soil layers until $120 \mathrm{~cm}$ depth. Mathematical relationships are taken from NITCROS (Hansen and Aslyng, 1984), FIELD (Duffy et al., 1977), and Verbruggen (1985). The model was validated using field trial data of a nitrogen fertilizer experiment ( $4 \mathrm{~N}$-levels) on a loamy soil during the seasons 1983 and 1984.

SUBEMO (Vandendriessche, 1989) simulates a pool of carbohydrates in beet resulting from photosynthesis and recuperation of dry matter from ageing and dying leaves. The pool of carbohydrates is depleted to sustain respiration, growth and sugar accumulation. Dry matter partitioning is approached by the following teleonomic partitioning hypothesis. At plant level, when the plant is faced with a given environment, dry matter is allocated to the different plant organs, including sugar accumulation, in such a way that the plant attains an optimal specific growth rate in that given environment.

SIUCRA (Burke, 1992) was developed to simulate the growth and development of sugar beet in Ireland. The central routine of the model describes photosynthesis by the crop as a function of photosynthetic active radiation, temperature, leaf area index and some crop specific parameters such as photosynthetic efficiency. If water is limiting, the calculated amount of carbohydrates is adjusted according to the degree of water stress currently existing in the crop. In the next step of the model, the maintenance respiration rate and the amount of carbohydrates which are available for growth are calculated. The partitioning of these carbohydrates to the various plant parts depends on the development stage of the crop. SIUCRA updates the state of the crop on a daily basis. Besides dry weight per hectare of roots, leaves and petioles and the development stage of the crop, it is also possible to include the soil moisture deficit as being a part of the representation of the crop state. The Test Reference Year (TRY) is an essential part of running the model for yield prediction. The TRY is a data file containing meteorological data representing a 'typical' year. It is used to project the weather to the end of the growing season.

The weak point of the above-described mechanistic simulation models is the physiological basis of assimilate distribution. This item requires further analysis in order to describe the translocation process and the growth of the competing organs more accurately and this can be a positive contribution to improve the predictive power of the mechanistic models. Table 3 shows that sugar beet models seldom include a water or a nitrogen balance submodel. Such a balance can be modified by cultural practices to maximize yield and sugar beet quality and is therefore important to reveal inefficiencies in agricultural management at field level. This is extremely important in those cases 
where the financial return of sugar beets is determined by numerous yield and quality factors (Vandendriessche et al., 1990). This depends of course on the current price systems. For example in the Netherlands the price received by the farmers for 1 ha of sugar beet depends on root yield, sugar content and the content of $\alpha$-amino-nitrogen, potassium and sodium, while in Belgium the price depends only on root yield and sugar content. Table 3 also shows clearly that, so far, no attempts have been made to model sugar beet quality in terms of $\alpha$-amino-nitrogen, potassium and sodium contents. Only a few mechanistic models deal with sugar accumulation. However the quality of sugar beet is of scientific and economic interest.

\section{FARM LEVEL DECISION SUPPORT SYSTEMS}

Automation is becoming more and more part of modern agriculture. Farmers are confronted with a very broad and rapidly expanding range of farming techniques designed to increase and ensure production, to optimize productivity and to promote quality. Making the right operational, tactical or strategic decisions can become so complex that computerized methods to deal with most production factors with regard to farm and field specific conditions are desirable. A good decision-making program could avoid miscalculations concerning the use of the wrong product, in the wrong way, at the wrong time, resulting in negative economic and ecological effects. The most direct role for decision support systems is the training and advising of individual farmers and extension agents.

Decision support tools normally involve interactive inclusion of both objective data as well as subjective knowledge (expert) rules. The derivation of expert rules requires the structuring and intelligent use of accumulated information (Barrett, 1992). Based on a classification of Jones (1989) three types of expert systems used for decision support in growth of sugar beet can be distinguished. First, heuristic expert systems based on the heuristic knowledge of an expert. Secondly, model-based expert systems that link simulation models and expert systems to facilitate the use of proven models through expert system parameterization and/or interpretation of results. Thirdly, expert databases that link databases and expert systems to facilitate the search for the most relevant information.

Table 4 gives a review of crop models, and different kinds of expert systems developed for decision support and farm management in sugar beet cultivation. A short description of each of the systems listed is given below.

Some of these systems are developed for decision support on plural aspects of sugar beet growing (BETA, BETAKWIK, BOB, SAKARA). Others treat a single aspect: BETTY diagnoses diseases, nutrient shortage and pests of sugar beet ; BETSY is an expert system for weed control ; N-INDEX calculates fieldspecific nitrogen fertilizer advice.

The various systems differ in the way they communicate with the user (user interface). Three user interfaces can be distinguished: (1) personalized letters; (2) computerized systems ; and (3) telematic systems.

The basic idea behind the crop management system BETA (de Jong, 1990; Kemp Hakkert, 1992) is to give specific, accurate and up-to-date advice by combining field-specific data, field observations and latest research results. BETA contains normative data such as sensitivity tables for herbicides and pesticides and cultivar notes, which have to be updated regularly. Field-specific advice is given concerning sowing, re-sowing, fertilizer use and crop protection. BETA runs as a stand-alone program on the farmer's microcomputer. No external organization is able to interfere with the farm specific data which controls the advice. Another aim of BETA is to create a standard for a comprehensive farm management information system which includes other crops besides sugar beet. Commercialization of BETA was not successful because of its complexity, its price and the program maintenance. Therefore a more simple program BETAKWIK is developed from important sub parts of BETA. BETAKWIK treats the following subjects: cultivar choice, N-, P- and K-fertilization, liming, weedcontrol, re-sowing, treatments of pests and diseases, costs for tare and harvest losses (Anonymous, 1994; Kemp Hakkert, 1994).

The Beet Growers Card, abbreviated to $\mathrm{BOB}$, (in Swedish 'BetOdlarBrev'; Landquist and Jeppsson, 1992), is an advisory system based on a selection of existing data bases, and field monitoring (Landquist and Jeppsson, 1992). The system gives individual advice to participating growers. They receive 8 to 15 cards during the growing period, with specific management recommendations. At the end of the season a complete evaluation of the economic (i.e. production costs) and biological (i.e. incidence of diseases) aspects of the sugar beet crop are provided. As an extra inducement, every year a 'Special Aid' in the form of a folder or a plastic card with special information about a typical sugar beet topic is distributed to the participating growers. For example, in 1990 a folder about weed control with recommendations concerning each of the 23 most common weeds, was given to the participating growers.

SAKARA is an expert system for improving sugar beet yield (Vion, 1992). The system compares fieldspecific information with a knowledge base concerning 16 items relevant to agronomic, technical and economic aspects of the sugar beet crop. SAKARA manipulates the knowledge in a symbolic rather than a numeric way. When the inference engine discovers a discordance between the field specific information and 
Table 4. Main characteristics of some published decision support systems for sugar beets on farm or field level.

\begin{tabular}{|c|c|c|c|c|c|c|c|c|c|}
\hline \multirow[b]{2}{*}{ Name } & \multicolumn{3}{|c|}{ Approach } & \multirow{2}{*}{$\begin{array}{c}\text { Program } \\
\text { language } \\
\text { and/or } \\
\text { development } \\
\text { tool }\end{array}$} & \multirow[b]{2}{*}{$\begin{array}{l}\text { User } \\
\text { interface }\end{array}$} & \multirow[b]{2}{*}{$\begin{array}{l}\text { Applied into the } \\
\text { field }\end{array}$} & \multirow[b]{2}{*}{$\begin{array}{l}\text { User } \\
\text { pays } \\
\text { for the } \\
\text { system }\end{array}$} & \multirow[b]{2}{*}{$\begin{array}{l}\text { Developed } \\
\text { in }\end{array}$} & \multirow[b]{2}{*}{ References } \\
\hline & $\begin{array}{l}\text { Heuristic } \\
\text { expert } \\
\text { system }\end{array}$ & $\begin{array}{l}\text { Model- } \\
\text { based } \\
\text { expert } \\
\text { system }\end{array}$ & $\begin{array}{l}\text { Expert- } \\
\text { data- } \\
\text { bases }\end{array}$ & & & & & & \\
\hline BETA & & . & $x$ & Dataflex 3.0 & $\begin{array}{l}\text { Personal } \\
\text { Computer }\end{array}$ & $\begin{array}{l}\text { by } 50 \text { farmers; } \\
\text { commercialisation } \\
\text { ended in january } \\
1994\end{array}$ & $\mathrm{x}$ & $\begin{array}{l}\text { The } \\
\text { Netherlands }\end{array}$ & $\begin{array}{l}\text { de Jong, } \\
1990 \\
\text { Kemp } \\
\text { Hakkert, } \\
1992\end{array}$ \\
\hline BETA-KWIK & . & & $\mathrm{x}$ & D-BASE & $\begin{array}{l}\text { Personal } \\
\text { Computer }\end{array}$ & $\begin{array}{l}\text { tested in } 1993 \text { by } \\
200 \text { farmers and the } \\
\text { extension service of } \\
\text { the Sugar Industry }\end{array}$ & $x$ & $\begin{array}{l}\text { The } \\
\text { Netherlands }\end{array}$ & $\begin{array}{l}\text { Kemp } \\
\text { Hakkert, } \\
1994\end{array}$ \\
\hline BETSY & $\mathrm{x}$ & & $\mathrm{x}$ & $\begin{array}{l}\text { EXPERTIS } \\
\mathrm{C}++\end{array}$ & Telematic & $\begin{array}{l}5000 \text { communications } \\
\text { during May-June }\end{array}$ & & France & $\begin{array}{c}\text { Escriou, } 1992 \\
\ldots\end{array}$ \\
\hline BETTY & $\mathrm{x}$ & & & $\begin{array}{l}\text { LISP } \\
\text { MIRA }\end{array}$ & Telematic & $\begin{array}{l}\text { only used as a } \\
\text { prototype }\end{array}$ & . & France & $\begin{array}{l}\text { Lamarque, } \\
1992\end{array}$ \\
\hline $\mathrm{BOB}$ & $x\left({ }^{1}\right)$ & & $x\left(\left(^{1}\right)\right.$ & SAS & $\begin{array}{l}\text { Personalized } \\
\text { letters }\end{array}$ & $\begin{array}{l}82 \% \text { of the } \\
\text { Swedish beet } \\
\text { growers are involved } \\
=88 \% \text { of total } \\
\text { beet growing area }\end{array}$ & $x$ & Sweden & $\begin{array}{l}\text { Landquist } \\
\text { and Jeppsson, } \\
1992\end{array}$ \\
\hline N-INDEX & (x) & $\mathrm{x}$ & $x$ & $\begin{array}{l}\text { FORTRAN } \\
\text { SQL }\end{array}$ & $\begin{array}{l}\text { Personalized } \\
\text { letters }\end{array}$ & $\begin{array}{l}\text { successfully applied } \\
\text { in Belgium and the } \\
\text { northern part of } \\
\text { France }\end{array}$ & $\mathrm{x}$ & Belgium & $\begin{array}{l}\text { Vanstallen } \\
\text { and Boon, } \\
1983 \\
\text { Vanden- } \\
\text { driessche et } \\
\text { al., } 1992\end{array}$ \\
\hline SAKARA & $\mathrm{x}$ & & $x$ & VP EXPERT & & & & France & Vion, 1992 \\
\hline Unnamed & $\mathrm{x}$ & & & Multiplan & & $\begin{array}{l}\text { developed for } \\
\text { research purposes } \\
\text { only }\end{array}$ & & Germany & Wagner, 1993 \\
\hline
\end{tabular}

(') The authors did not explicitly describe BOB as an expert system.

the knowledge base, SAKARA gives a message. Also, the technical and economical results of the field are compared with the results of a reference group within the database.

The N-INDEX method (Vanstallen and Boon, 1983 ; Vandendriessche et al., 1992) is a field specific advice-system for $\mathrm{N}$-fertilizer recommendation for most arable and vegetable crops, including sugar beet. The knowledge base contains results of field trials and includes specific production functions and production rules concerning the sugar beet crop. The inputs required are the mineral nitrogen reserve in the soil between 0-90 cm measured in January-May, sugar beet cultivar, sowing and harvest date, and amount, date and kind of organic matter application, inclusive of green manure. The participating growers receive a 2 or 3 page bulletin with the nitrogen status, $\mathrm{pH}$ and carbon content of the soil, the recommended rate of application of nitrogen fertilizer and, if necessary, important and useful recommendations.

BETSY (Escriou, 1992) is an expert telematics system for weed control in sugar beet. The know-how of specialists of the 'Institut Technique de la Betterave (I.T.B.)' on the use of herbicides forms the knowledge base of BETSY.

BETTY is an expert system developed by INRA to diagnose diseases, nutrient shortage and some pests of the sugar beet crop (Lamarque, 1992). The validation 
of BETTY was done in two phases. The first validation phase was concomitant with the development of the knowledge base (1985-1988), and the second one occurred later, on the fields during different growing seasons until 1990.

Wagner (1993) describes a model using production functions to determine the optimal variety of sugar beet seed. The experts' knowledge is transformed into mathematical relations using linear, non-linear and non-monotonic functions. The inputs expected from the program user are weather data, price of roots and leaves, and beet cultivars. The user interface is a tabulated result of sugar beet yield, financial return and a ranking of the beet cultivars given in the input.

Most of the above-described decision support systems are only used at an experimental level. There are only a few examples of successful application, viz. BOB and N-INDEX. The reasons for success of these systems may be that they give advice which is to the point, precise, and quick and easy to understand. The sugar beet growers only have to read a card or a bulletin and do not need a micro computer. Nevertheless, the interest in telematic and computerized user interfaces is increasing. Besides, these successful systems are designed and supported by agricultural companies closely related to farmers. BOB is a project in co-operation between the Swedish Sugar Beet Growers Association (SBC) and the Swedish Sugar Company (SSA). The research. and application of N-INDEX is a realization of the $R$ and $D$ department of the Soil Service of Belgium.

A significant problem hindering the application of expert systems and models is the poor availability of crop and field data. Much crop cultivation information is insufficiently quantitative for detailed field-specific decision schemes. In future much attention should be given to quantification of research information in such a way that it can be used for crop management and decision support systems for several crops (Kemp Hakkert, 1992).

\section{CONCLUSIONS}

Sugar beet modelling has, broadly speaking, three aims : yield forecasting, research development and the design of decision support systems. To forecast yield two broad categories of crop models are available: empirical descriptive and mechanistic explanatory models. Descriptive models are not by definition inferior to explanatory models. On the contrary they are very useful in the region and for the purpose for which they are developed. Various empirical models are used and are able to describe yield and sugar variations in relation to environmental factors with a high degree of success.

For research purposes mechanistic models are commonly used. Mechanistic models can portray the response of sugar beet to environmental, site and sometimes even management variables. Many processes like photosynthesis, transpiration, growth, respiration and yield partitioning are described in mechanistic sugar beet models. So far no attempts have been made to model the process of sugar beet quality in terms of $\alpha$-amino-nitrogen, potassium and sodium accumulation. In addition, only a few mechanistic models tackle the process of sugar accumulation.

Decision support systems mostly consist of a combination of data processing and knowledge rules. BOB and N-INDEX are successful examples with a narrow domain of application. Great attention is paid to follow-up and quick support.

Mathematical models do not only enclose data and knowledge, but, suitably programmed and managed, they can make data and knowledge accessible to and usable by the non-expert, the non-researchers, extension staff and farmers.

\section{ACKNOWLEDGEMENTS}

The authors are grateful to Prof. J. Feyen and Prof. $R$. Rabbinge for valuable advice on the manuscript.

\section{REFERENCES}

Anonymous (1994). Suikerindustrie introduceert teeltbegeleidingsprogramma BETAKWIK. CSM-Informatie, 484, 22-23.

Barrett J. R. (1992). Knowledge Engineering in Energy Systems. In: B. A. Stout (Ed-in-chief), R. M. Peart and R. C. Brook (Eds.), Energy in World Agriculture, 5 (1992), Analysis of Agricultural Energy Systems, pp. 1-8.

Belmans C., Wesseling J. G. and Feddes R. A. (1982). Simulation model of the water balance of a cropped soil : SWATRE. J. Hydrol., 63, 271-286.

Biemond T., Greve H. J., Schiphouwer T. and Verhage A. J. (1989). PIEteR : Semi green-box produktiemodel suikerbieten. LU Wageningen, Vakgroep Agrarische Bedrijfseconomie, $31 \mathrm{p}$.

Bouman B. A. M. (1991). Linking X-band radar backscattering and optical reflectance with crop growth models. $\mathrm{Ph}$. D. Thesis, Wageningen Agricultural University, The Netherlands, $169 \mathrm{p}$.

Bouman B. A. M. (1992). SBFLEVO. Growth models to simulate crop growth, optical Flevoland. Cabo-DLO, Report 163, August 1992, $101 \mathrm{pp}$.

Burke J. I. (1992). A Physiological Growth model for Forecasting Sugar Beet Yield in Ireland. Proceedings of the IIRB 55th Winter Congress, 239-251.

Church B. M. and Gnanasakthy A. (1983). Estimating sugar production from preharvest samples. Br. Sugar Beet Rev., 51, 3, 9-11.

Day W. (1986). A simple model to describe variation between years in early growth of sugar beet. Field Crops Res., 14, 213-220.

de Jong P. C. (1990). BETA : a decision support system for the cropping of sugar beet, approach and first expierences. Pro- 
ceedings 3th International Computer congress, 27-30 May 1990, organized by DLG, RASE and SAF, 90-99.

Duffy J., Chung C., Franklin M. and Boast C. (1977). Reference manual for FIELD, a program for the simulation of nitrogen flow in a tile-drained .Corn Belt agricultural field. CBNS Washington University, Saint-Louis, Missouri, 103 p.

Escriou H. (1992). BETSY : système expert télématique pour le désherbage de betteraves sucrières. Proceedings of the IIRB 55th winter congress, 63-68.

Feyen J. and Van Aelst P. (1983). Test of a simple growth model simulating sugar beet yields. Pédologie, 33, 3, 281293.

Fick G. W. (1971). Analysis and simulation of the growth of sugar beet (Beta vulgaris L.). Ph.D. thesis, University of California, Davis, $222 \mathrm{p}$.

Fick G. W., Williams W. A. and Loomis R. S. (1973). Computer simulation of dry matter distribution during sugar beet growth. Crop Sci., 13, 413-417.

Fick G. W. Loomis R. S. and Williams W. A. (1975). Sugar beet. In : Evans L. T. (Ed.), Crop Physiol., Cambridge University Press, 259-295.

France J. and Thomley J. H. M. (1984). Mathematical models in agriculture. London: Butterworths, $335 \mathrm{p}$.

Frere M. H., Jensen M.E. and Carter J. N. (1970). Modeling water and nitrogen behavior in the soil plant system. Proceedings of the 1970 summer computer simulation conference, Denver, Colorado, 746-450.

Hansen S. and Aslyng H. C. (1984). Nitrogen balance in crop production. Simulation model NITCROS. Hydrotechnical laboratory, the Royal Veterinary and Agricultural University, Copenhagen, $113 \mathrm{p}$.

Hendrickx G. (1986). Het water- en stikstofgedrag in het bodem-plantsysteem bij suikerbieten, simulatie en validatie. Eindwerk, K.U. Leuven, 145 p.

Hunt W. F. (1974). Respiratory control and its prediction by a dynamic model of sugar beet growth. Ph.D. thesis, University of California, Davis, 243 p.

Hunt W. F. and Loomis R. S. (1979). Respiration modelling and hypothesis testing with a dynamic model of sugar beet growth. Ann. Bot., 44, 5-17.

Jaggard K. and Clark C. (1990). Predicting yield for the sugar industry. Br: Sugar; 58, 4, 40-43.

Jaggard K.W. (1992). Remote sensing to forecast yield in England. Proceedings of the IIRB 55th winter congress, 253260.

Jones P. (1989). Agricultural Applications of Expert Systems Concepts. Agric. Syst., 31, 3-18.

Kemp Hakkert D. J. (1992). BETA, a crop management system for sugar beet : development and experiences. Proceedings of the IIRB 55th winter congress, 53-62.

Kemp Hakkert D. J. (1994). Teeltbegeleidingsprogramma BETAKWIK nu bestellen! CSM-Informatie, 485, 14-15.

Kropff M. J. (1993). Eco-Physiological Models for Crop-Weed Competition. In : Kropff M. J. and van Laar, H. H. (Eds.). Modelling crop-Weed Interactions, CAB International, 274 p.

Krupa S., Nosal M. and Legge A. (1992). Modelling plant response to troposheric ozone : concepts and strategies. In : H. J. Jäger, M. Unsworth, L. De Temmerman and P. Mathy (Eds.). Proceedings of the final symposium of the European Open-Top Chambers project on Effects of Air Pollution on Agricultural Crops in Europe, pp. 131-150.

Lamarque C. (1992). BETTY : maintien et evolution du système expert de diagnostic sur les maladies et accidents culturaux de la betterave. Proceedings of the IIRB 55th winter congress, 73-76.
Landquist B. and Jeppsson R. (1992). Beet Growers Card- the Information System that gives the Right Grower the Right Advice at the Right Time. Proceedings of the IIRB 55th winter congress, 33-43.

Lee G. S. (1983). Conceptual Development of a sugarbeet crop growth model. Ph.D. thesis, Colorado State University, Fort Collins, Colorado, $265 \mathrm{p}$.

Maas S. J. (1988). Use of remotely-sensed information in agricultural crop models. Ecol. Model., 41, 247-268.

Mambelli S., Vitali G., Venturi G. and Amaducci M. T. (1992). Simulation model for predicting sugar beet growth and sugar yield under Po-valley conditions. Proceedings of the IIRB 55 th winter congress, 305-314.

Modig S. A. (1992). Swedish Forecasts of sugar beet yields Some Regression Models. Proceedings of the IIRB 55th winter congress, 189-210.

Monteith J. L. (1965). Light distribution and photosynthesis in field crops. Ann. Bot., 29, 17-37.

Patefield W. M. and Austin R. B. (1971). A model for the simulation of the growth of Beta vulgaris L. Ann. Bot., 35, 1227 1250.

Penning de Vries F. W. T. (1983). Modeling of growth and production. In : O. L. Lange, P. S. Nobel, C. B. Osmond and H. Ziegler (Eds.), Physiological Plant Ecology. IV. Encyclopedia of Plant Physiology; New Series, 12D. New York; SpringerVerlag, pp. 117-150.

Ritchie J. T. (1984). A user oriented model of the soil water balance in wheat. USDA-ARS, Soil and Water Research Laboratory, Temple, Texas, $21 \mathrm{p}$.

Scott R. K. and Jaggard K. W. (1993). Crop physiology and agronomy. In: D. A. Cooke and R. K. Scott (Eds.), The Sugar Beet Crop: Science into practice. London : Chapman and Hall, pp. 179- 237.

Seligman N. G. (1990). The crop model record: promise or a poor show? In : R. Rabbinge, J. Goudriaan, H. van Keulen, F. W. T. Penning de Vries and H. H. van Laar (Eds.), Theoretical production ecology: reflections and prospects. Simulation Monograph 34, Wageningen : Pudoc, pp. 249-263.

Seligman N. G. and van Keulen H. (1981). PAPRAN : a simulation model of annual pasture production limited by rainfall and nitrogen. In: N. H. Frissel and J. A. Van Veen (Eds.), Simulation of nitrogen behaviour of soil-plant systems. Wageningen: Pudoc, $27 \mathrm{p}$.

Smit A. B., van Niejenhuis J. H. and Struik P. C. (1993). Introduction to a bio-economic production model for sugar beet growing. In : Proceedings of 'Plant Production on the threshold of new century'. Wageningen June 28-July 11993.

Spitters C. J. T., van Keulen H. and van Kraalingen D. W. G. (1989). A simple and universal crop growth simulator: SUCROS87. In: Rabbinge R., Ward S. A. and van Laar H. H. (Eds.), Simulation and systems management in crop protection. Simulation Monographs 32, Pudoc, Wageningen : pp. 147-181.

Spitters C. J. T., Kiewiet B. and Schiphouwer T. (1990). A weather-based yield-forecasting model for sugar beet. Neth. J. agric. Sci., 38, 731-735.

Thornley J. H. M. and Johnson I. R. (1990). Plant and crop modelling. A mathematical approach to plant and crop physiology. Oxford ; Clarendon press, $669 \mathrm{p}$.

Vandendriessche H. (1989). Het suikerbietenmodel SUBEMO. In: Simulatie als hulpmiddel bij het stikstofbemestingsadvies voor de teelten wintertarwe en suikerbieten, I.W.O.N.L., 83-108.

Vandendriessche H., Geypens M. and Bries J. (1990). Adjustment of fertilizer dressings to achieve high quality and optimum price for potatoes and sugar beet. In : Proc. $22^{\text {nd }}$ Colloqium Int. Potash Institute, Bern, 359-371. 
Vandendriessche H., Geypens M. and Bries J. (1992). De stikstofbemesting van akkerbouwteelten in relatie tot het milieu. Landbouwtijdschrift, 45, 2, 395-403.

van der Beek M. A. (1993). Groeiverlooponderzoek, met speciale aandacht voor het suikergehalte. I.R.S.-dag, 3 juni 1993. Bergen op Zoom I.R.S.

van der Werf W. (1988). Yellowing viruses in sugar beet: epidemiology and damage. Ph.D. thesis, Agricultural University, Wageningen, pp. 152.

van Keulen H. and van Laar H. H. (1982). The relation between water use and crop production. In : van Keulen $\mathrm{H}$. and Wolf J. (Eds.), Modelling of agricultural production: weather; soils and crops. Simulation Monographs, Wageningen; Pudoc, pp. 117-129.

van Laar H. H., Goudriaan J. and van Keulen H. (1992). Simulation of crop growth for potential and water limited production situations. Simulation Reports, 27, $76 \mathrm{p}$.

Vanstallen R. and Boon R. (1983). De stikstofbemesting van suikerbieten. Landbouwtijdschrift, 36, 3.
Verbruggen J. (1985). Simulatie van het denitrificatieproces in de bodem. Dissertationes de Agricultura, K.U. Leuven, 180 p.

Vion J.M. (1992). SAKARA: Système expert pour l'amélioration de la productivité des betteraves sucrières. Proceedings of the IIRB 55th winter congress, 17-31.

Vossen P. (1992). Timely forecasting of national sugar beet production in Europe: the C.E.C. methodology and planned improvements using data from satellites. Proceedings of the IIRB 55th winter congress, 261-281.

Wagner P. (1993). Techniques of Representing Knowledge in Knowledge - Based Systems. Agric. Syst., 41, 53-76.

de Wit C. T. (1965). Photosynthesis of leaf canopies. Versl. Landbouwk. Onderz., Wageningen, No. 663.

Yücel S. (1992). Relationships between sugar beet yield and quality and climatic factors in Turkey. Proceedings of the IIRB 55th winter congress, 223-238. 